\title{
Reading Strategies Employed by Business English Majors with Different Levels of Exposure to Specialized Courses
}

\author{
Jun Chen \\ School of Foreign Languages, Institute of Social Technology, Suranaree University of Technology, Nakhon Ratchasima \\ 30000, Thailand \\ Channarong Intaraprasert \\ School of Foreign Languages, Institute of Social Technology, Suranaree University of Technology, Nakhon Ratchasima \\ 30000, Thailand
}

\begin{abstract}
This study investigated the use of reading strategies by the university Business English majors in relation to their levels of exposure to specialized courses. The participants were 926 university Business English majors from 6 universities in Southwest China. A Strategy Questionnaire for Business English Reading was used to collect the data. The results revealed that the overall use of reading strategies between the students with less and more exposure to specialized courses had no significant variations At the category level, the students with less exposure to specialized courses reported significantly more use of the strategies in the POS category than the students with more exposure to specialized courses, while the students with more exposure to specialized courses reported using the strategies in the SCT sub-category of WHS category significantly more frequently than the students with less exposure to specialized courses. In terms of the individual strategy use, 18 out the 45 strategies across the questionnaire showed significant variations. Overall, the students with less exposure to specialized courses reported employing the individual strategies significantly more frequently than the students with more exposure to specialized courses.
\end{abstract}

Index Terms — reading strategies, Business English major, level of exposure to specialized courses

\section{INTRODUCTION}

"Reading is an active and fluent process which involves the reader and the reading material in building meaning." (Anderson, 1999, p. 1). Goodman (1995, p. 12) states that "Reading is a receptive language process. It is a psycholinguistic process in that it starts with a linguistic surface representation encoded by a writer and ends with meaning which the reader constructs". Reading comprehension is the interaction between the reader and the text. It is an active process in which the reader infers and interprets what is on the page based on individual attitudes, interest, expectations, skills and prior knowledge he or she brings to the reading task (Irwin (1986). Reading plays a crucial role in language learning. It is one of the most important language skills that students should be equipped with. It is through reading that the students access a lot of information concerning the target language and culture. For either ESL or EFL learners, it is the important skill to master in order to ensure success in language learning (Anderson, 1999).

Reading strategies are "deliberate, cognitive steps that readers can take to assist in acquiring, storing and retrieving new information" (Anderson, 1991, p. 460). It is a physical or mental action used consciously or unconsciously with the intention of facilitating comprehension in reading (Davies, 1995). They are a set of abilities under conscious control of the reader. Reading strategies play a crucial role in ESL and EFL reading. As Song (1998) asserts, reading strategies are important because they can help the readers facilitate reading comprehension and enhance reading efficiency. Researchers have long recognized the strong relationship between the use of reading strategies and the reading achievement. The success in reading is linked to the quality and quantity of reading strategies used (Oxford, 1989; Brown, 1989; Alderson, 2000). Many studies have revealed that the strategic readers are good at drawing on a variety of strategies to accomplish the purposes of reading. Effective readers are more aware of strategy use than less effective readers (e.g. Hosenfield, 1977; Block, 1986; Anderson, 1991; 1992; Sheory and Mokhtari, 2001; Anastasiou and Griva, 2009; Maarof and Yaacob, 2011).

In China, the studies on reading strategies are very few. The research in this field was mainly conducted in the university context, using the university students as participants. These studies mainly focus on investigating the relationships between the reading strategies and reading proficiency (Liu, 2002; Liu 2004; Liu and Zhang, 2008; Zhang and $\mathrm{Wu}, 2009$; Luo 2010). The results of these studies revealed that there were some correlations between the readers' reading proficiency and their reading strategy use. The strategies used by proficient readers and less proficient readers varied significantly. Generally, students with higher reading proficiency reported employing reading strategies significantly more frequently than the students with lower reading proficiency. Only one or two researchers investigated 
the students' use of reading strategies in relation to some other variables, such as gender (Luo and Han, 2011); field of study, teacher' gender, type of university, and students' extensive reading (Luo, 2010). The findings of these studies showed that some variables, such as the students' gender and extensive reading, had significant correlation with the students' use of reading strategies. To the best knowledge of the researcher, up to the present, no empirical studies have been carried out specifically to investigate the use of reading strategies by university Business English majors in relation to their levels of exposure to specialized courses. The purpose of this study is intended to fill in this gap.

Schema theory emphasizes the influence of learners' background knowledge on reading comprehension. Brown (2001) classifies schemata into two categories: content schemata and formal schemata. The former refers to the knowledge of people, the world, culture and the universe, whereas the latter refers to the knowledge of the structure of texts. The background knowledge relating to the topic may assist the readers in learning from the text (Hayes and Tierney, 1982). Research has revealed that comprehension can be achieved more easily if the readers have appropriate schemata or frames about the new information being presented in the reading texts than the readers who lack the schemata to fit the new information (Anderson, 2004). Some reading strategies relating to readers' schemata, such as previewing text and examining the title and subheadings, can help to improve the readers' comprehension of both explicit and implicit information (Grave and Cooke, 1980). Wenden (1991) states that the use of strategies is the outcome of a variety of factors, especially the subjects' background knowledge about subject matter content and about learning, the nature of the materials to be learned and the product or outcome that the learner has in mind.

In China, the Business English program is mainly divided into the lower-year stage (the first and the second years) and higher-year stage (the third and the fourth year). The focus of the lower-year stage is on the students' improvement in language skills although the students also learn some basic courses about business. Language learning is in the first place and content knowledge learning is in the second in this phase. In higher-year stage, the focus is on the learning of Business courses using English as the medium. In this stage, content knowledge learning is in the first place and language learning is in the second. The degrees of contacting with the business content between the students of the two stages are obviously different. According to Oxford (1990), stage of learning is one of the factors that may influence learners' strategy choice. Therefore, it can be hypothesized that the students of the two groups may employ different reading strategies to deal with the content reading. The level of exposure to specialized materials can be seen as a factor of learning experience that may have impact on the students' choices of reading strategies. So far, this factor has not been taken into consideration in the previous reading strategy research. For this reason, it is worthy and necessary to take this variable into the present study to examine whether there is relationship between the use of reading strategies by the university Business English majors and the their levels of exposure to the specialized courses in the ESP context. The research questions are: Do the reading strategies employed by university Business English majors vary significantly in terms of their levels of exposure to specialized courses at the overall, category and individual levels? If they do, what are the main patterns of variation?

\section{ReSEARCh Methodology}

\section{A. Key Terms of the Present Study}

Business English Majors

"Business English majors" in the present study refers to the university students in Southwest China who major in the business-oriented English program. It is an English-medium program, in which the students are required to learn the English language used in the communication of the international business as well as the specialized courses concerning international trade, commerce and economics. using English as the medium.

Reading Strategies

"Reading strategies" in the present study is defined as the skills, techniques, methods and behaviors that the university Business English majors employ to enhance their reading comprehension or solve their reading problems and difficulties when reading Business English texts (Chen and Intaraprasert, 2014, p. 27).

Level of Exposure to Specialized Courses

"Level of exposure to specialized courses" refers to the degree that the students contact with the specialized courses relating to international Business using English as the medium. In the present study, the students' levels of exposure to specialized were classified as 'less' (the first- and second-year students) and 'more' (the third- and fourth-year students), as the students in Business English program mainly learn language courses in the first two years and learn specialized courses in the last two years.

\section{B. Participants}

The participants for the present study were 926 university Business English majors selected from 6 universities in Southwest China through the use of cluster sampling method. Firstly, the researcher divided the population for the present study into 3 clusters: Guizhou Province, Yunnan Province and Chongqing City. Then 2 universities were selected from each of the clusters. Finally, the researcher selected the participants from the intact classes in each of the universities based on their availability and convenience. Totally, 312 students in Guizhou Province, 310 students in Yunnan Province and 304 students in Chongqing City were chosen for the present investigation. 


\section{Data Collection}

The instrument used to collect the data for the present investigation was the Strategy Questionnaire for Business English Reading (SQBER), which was adopted from Chen and Intaraprasert (2014). This questionnaire was constructed to investigate the strategy use of the university business English majors. The reading questionnaire comprises 45 strategy items, which were classified into 3 categories, i.e. 1) PRS category (Pre-reading Strategies), 2) WHS category (While-reading Strategies), and 3) POS category (Post-reading Strategies). The WHS category (While-reading Strategies) was further divided into SCT (Strategies for Comprehending the Text) and SCD (Strategies for Coping with Difficulties) sub-categories. A 4-point rating scale adopted from Intaraprasert (2000) was used to determine the frequency levels of the students' reading strategy use. The scales were valued as 1, 2, 3, and 4, which represented 'Never', 'Sometimes', 'Often' and 'Always/Almost always'. The internal reliability estimate of Alpha Coefficient $(\alpha)$ of the questionnaire was .91 based on the responses of the 926 participants, which was much higher than the acceptable reliability coefficient of .70 .

\section{Data Analysis}

The data obtained from the questionnaires were inputted into the computer and SPSS program was conducted to analyze the data. The statistical methods used in the present study included the ANOVA (Analysis of Variance) and the Chi-square test. The ANOVA was employed to examine the variations of the students' strategy use at the overall and category levels. The Chi-square test was employed to examine the variations of the students' use of reading strategies at the individual strategy level.

\section{RESULTS}

The following is the findings of the present study. The results are reported in a top-down manner. That is, the variations in the frequency of students' strategy use according to their levels of reading proficiency are presented at the overall, category and individual levels in sequence.

\section{A. $\quad$ Variations in Frequency of Students' Overall Reading Strategy Use}

The results of ANOVA are summarized in Table 1 below, which consists of the variable, mean frequency score (mean), standard deviation (S.D.), significant level and variation patterns in frequency of strategy use. As shown in Table 1, the students' overall strategy use did not vary significantly according to the students' level of exposure to specialized courses ( $p>.05)$. That is to say, no significant variations existed in the frequency of overall strategy use between the students with more and less exposure to specialized courses.

TABLE I

\begin{tabular}{lccccc}
\multicolumn{5}{c}{ VARIATION IN FREQUENCY OF STUDENTS' } \\
\hline Variable & \multicolumn{5}{c}{ OVERALL READING STRATEGY USE } \\
\hline Level of Exposure to & More & 2.39 & S.D. & Sig. Level & Variation Pattern \\
Specialized Courses & Less & 2.40 & .33 & N.S. & -34 \\
\hline \multicolumn{7}{c}{ Note: N.S. stands for no significance } &
\end{tabular}

\section{B. Variations in Frequency of Students' Strategy Use in the Categories}

As mentioned earlier, the reading strategies were classified into three categories of PRS (While-reading Strategies), WHS (While-reading Strategies) and POS (Post-reading Strategies). The results of ANOVA in Table 2 showed that the students' reading strategy use in the POS category varied significantly according to their levels of exposure to specialized courses $(\mathrm{p}<.05)$. The mean frequency score of the students with less exposure to specialized courses (2.26) was higher than the students with more exposure to specialized courses (2.19), indicating that the students with less exposure to specialized courses employed reading strategies significantly more frequently than the students with more exposure to specialized courses in the post-reading stage. No significant variations in the use of reading strategies in the PRS and WHS categories were found between the two groups of students.

TABLE II

VARIATION IN FREQUENCY OF STUDENTS' READING STRATEGY USE IN THE CATEGORY

\begin{tabular}{|c|c|c|c|c|c|c|}
\hline \multirow{2}{*}{ Strategy Category } & \multicolumn{2}{|c|}{ More $(n=462)$} & \multicolumn{2}{|c|}{ Less $(n=464)$} & \multirow{2}{*}{$\begin{array}{l}\text { Sig. } \\
\text { Level }\end{array}$} & \multirow{2}{*}{ Variation Pattern } \\
\hline & Mean & S.D. & Mean & S.D. & & \\
\hline PRS Category & 2.47 & .38 & 2.51 & .42 & N.S. & ----- \\
\hline WHS Category & 2.50 & .34 & 2.47 & .34 & N.S. & ----- \\
\hline POS Category & 2.19 & .47 & 2.26 & .43 & $\mathrm{P}<.05$ & Less $>$ More \\
\hline
\end{tabular}

When taking a closer look at the sub-categories of the WHS category, some differences appeared, although significant differences have not been found in the WHS category in terms of students' levels of exposure to specialized courses, significant differences of the students' reading strategy use were found in the SCT sub-category of the WHS category. The results of ANOVA showed that the students with more exposure to specialized courses reported using significantly more reading strategies than the students with less exposure to specialized courses. The students of the two 
groups did not differ significantly in the use of reading strategies in the SCD sub-category. The results are presented in Table 3 below.

TABLE III

VARIATION IN FREQUENCY OF STUDENTS' READING STRATEGY USE IN THE SUB-CATEGORY

\begin{tabular}{|c|c|c|c|c|c|c|}
\hline \multirow{2}{*}{ Sub-Category } & \multicolumn{2}{|c|}{ More $(n=462)$} & \multicolumn{2}{|c|}{ Less $(n=464)$} & \multirow{2}{*}{$\begin{array}{l}\text { Sig. } \\
\text { Level }\end{array}$} & \multirow{2}{*}{ Variation Pattern } \\
\hline & Mean & S.D. & Mean & S.D. & & \\
\hline SCT Category & 2.56 & .39 & 2.51 & .39 & $\mathrm{P}<.05$ & More>Less \\
\hline SCD Category & 2.42 & .36 & 2.43 & .35 & N.S. & ----- \\
\hline
\end{tabular}

\section{Variations in Frequency of Students' Individual Strategy Use}

Sections 3.1 and 3.2 have presented the variations in the students' reading strategy use at the overall and category levels. This section is to present the results of the Chi-square Tests. As mentioned earlier, the Chi-square Tests were used to examine the individual strategy items for significant variations in terms of the students' levels of exposure to specialized courses. To demonstrate the results of the Chi-square Tests, the percentage of the students reporting high use of the individual strategies ( 3 and 4 in the strategy questionnaire) and the observed Chi-square value $\left(\chi^{2}\right)$ which shows the strength of variation in use of each individual strategy were identified. As presented in Table 4, the results of the Chi-square tests showed that of the 45 reading strategies across the questionnaire, 18 strategies in the three categories of the PRS, WHS and POS varied significantly according to the students' levels of exposure to specialized courses. The results of the Chi-square tests revealed two patterns of variation: ' $L>M$ ' and ' $M>L$ '. ' $L>M$ ' refers that a significantly greater percentage of the students with less exposure to specialized than the students with more exposure to specialized reported high use of that particular strategy. ' $\mathrm{M}>\mathrm{L}$ ' refers that a significantly greater percentage of the students with more exposure to specialized courses than the students with less exposure to specialized courses reported high use of that particular strategy.

In the variation pattern of ' $\mathrm{L}>\mathrm{M}$ ', a significantly greater percentage of the students with less exposure to specialized courses than the students with more exposure to specialized courses reported high use of 12 reading strategies. Among the 12 strategies showing significant variation, three are the strategies for pre-reading, such as 'PRS4. Read or check the new word list', 'PRS5. Glance over the foot notes, tables and graphics', and 'PRS10. Make predictions or inference about the content of the text'; five are the strategies for while-reading (WHS), examples are: 'WHS4. Read every word and sentence slowly and carefully' and 'WHS18. Ask the teachers, classmates or friends for help'; four are the strategies for post-reading (POS), such as 'POS6. Read other resources about the same topic' and 'POS10. Discuss the problems and difficulties with teachers/friends'. Regarding the variation pattern of ' $\mathrm{L}>\mathrm{M}$ ', a significantly greater percentage of the students with more exposure to specialized courses than the students with less exposure to specialized courses reported high frequency of use of 6 reading strategies. Among these strategies, one is the strategy for pre-reading 'PRS3. Set goals or purposes of reading'; four are the strategies for while-reading, such as 'WHS2. Use specialized terms as clues or indications' and 'WHS17. Adjust the reading rate accordingly'. The last one is the strategy for post-reading 'POS1. Make critical comments and evaluations on the content of the text'.

In the ' $\mathrm{L}>\mathrm{M}$ ' pattern, over $50 \%$ of the students with less exposure to specialized courses reported high use of 5 strategies, while over $50 \%$ the students reported high use of only 2 strategies. The top three of this variation pattern are WHS10 (Take notes or mark important information in the text), WHS7 (Make use of the features of the text) and PRS4 (Read or check the new word list). In the variation pattern of ' $M>L$ ', more than $50 \%$ of the students with more exposure to specialized courses reported high use 5 strategies and there was only 1 strategy for the case of the students with less exposure to specialized courses. The top three of this variation pattern are WHS2 (Use specialized terms as clues or indications), WHS13 (Do fast reading first and peruse later) and WHS17 (Adjust the reading rate accordingly). 
TABLE III

VARIATION IN FREQUENCY OF STUDENTS' INDIVIDUAL READING STARTEGY USE

\begin{tabular}{|c|c|c|c|c|}
\hline \multirow{2}{*}{$\begin{array}{l}\text { Individual Learning Strategy } \\
\text { Less }>\text { More }-12 \text { strategies }\end{array}$} & \multicolumn{2}{|c|}{$\%$ of high use (3 and 4$)$} & \multirow{2}{*}{$\begin{array}{l}\text { Observed } \chi^{2} \\
\mathrm{P}<.05\end{array}$} & \multirow{2}{*}{ Comments } \\
\hline & More & Less & & \\
\hline $\begin{array}{l}\text { WHS10. Take notes or mark the important } \\
\text { information in the text. }\end{array}$ & 59.7 & 66.4 & $\chi^{2}=4.38 *$ & $\mathrm{~L}>\mathrm{M}$ \\
\hline WHS7. Make use of the features of the text. & 52.8 & 59.7 & $\chi^{2}=4.46 *$ & $\mathrm{~L}>\mathrm{M}$ \\
\hline PRS4. Read or check the new word list. & 48.3 & 57.3 & $\chi^{2}=7.62 * *$ & $\mathrm{~L}>\mathrm{M}$ \\
\hline $\begin{array}{l}\text { PRS5. Glance over the foot/end notes, tables } \\
\text { and graphics. }\end{array}$ & 46.8 & 55.0 & $\chi^{2}=6.23 *$ & $\mathrm{~L}>\mathrm{M}$ \\
\hline $\begin{array}{l}\text { PRS10. Make predictions/inference about the } \\
\text { content of the text. }\end{array}$ & 43.7 & 50.9 & $\chi^{2}=4.73 *$ & $\mathrm{~L}>\mathrm{M}$ \\
\hline WHS19. Translate the text into Chinese. & 37.7 & 45.9 & $\chi 2=6.47 *$ & $\mathrm{~L}>\mathrm{M}$ \\
\hline $\begin{array}{l}\text { POS7. Review the notes and marks one } \\
\text { made }\end{array}$ & 33.5 & 40.5 & $\chi^{2}=4.82 *$ & $\mathrm{~L}>\mathrm{M}$ \\
\hline POS4. Summarize the content of the text. & 31.4 & 40.5 & $\chi^{2}=8.38 * *$ & $\mathrm{~L}>\mathrm{M}$ \\
\hline $\begin{array}{l}\text { WHS4. Read every word and sentence } \\
\text { slowly and carefully }\end{array}$ & 31.3 & 38.8 & $\chi^{2}=5.91 *$ & $\mathrm{~L}>\mathrm{M}$ \\
\hline $\begin{array}{l}\text { WHS18. Ask the teachers, classmates or } \\
\text { friends for help. }\end{array}$ & 26.0 & 34.3 & $\chi^{2}=7.57 * *$ & $\mathrm{~L}>\mathrm{M}$ \\
\hline $\begin{array}{l}\text { POS10. Discuss the problems and } \\
\text { difficulties with teachers or friends. }\end{array}$ & 22.1 & 32.5 & $\chi^{2}=12.77 * * *$ & $\mathrm{~L}>\mathrm{M}$ \\
\hline $\begin{array}{l}\text { POS6. Read other resources about the same } \\
\text { topic. }\end{array}$ & 20.8 & 27.6 & $\chi^{2}=5.85^{*}$ & $\mathrm{~L}>\mathrm{M}$ \\
\hline More $>$ Less -6 strategies & More & Less & $\mathrm{P}<.05$ & Comments \\
\hline $\begin{array}{l}\text { WHS2. Use specialized terms as clues or } \\
\text { indications. }\end{array}$ & 81.4 & 31.9 & $\chi^{2}=23.08 * * *$ & $\mathrm{M}>\mathrm{L}$ \\
\hline $\begin{array}{l}\text { WHS13. Do fast reading first and peruse } \\
\text { later. }\end{array}$ & 64.3 & 55.4 & $\chi^{2}=7.63 * *$ & $\mathrm{M}>\mathrm{L}$ \\
\hline WHS17. Adjust the reading rate accordingly & 54.5 & 47.8 & $\chi^{2}=4.15^{*}$ & $\mathrm{M}>\mathrm{L}$ \\
\hline PRS3. Set goals or purposes of reading & 52.8 & 44.4 & $\chi^{2}=6.57 *$ & $\mathrm{M}>\mathrm{L}$ \\
\hline $\begin{array}{l}\text { WHS16. Analyze the structures of the } \\
\text { difficult sentences. }\end{array}$ & 40.5 & 30.6 & $\chi^{2}=9.85 * *$ & $\mathrm{M}>\mathrm{L}$ \\
\hline $\begin{array}{l}\text { POS1. Make critical comments and } \\
\text { evaluations on the content of the text. }\end{array}$ & 21.0 & 12.1 & $\chi^{2}=13.38 * * *$ & $\mathrm{M}>\mathrm{L}$ \\
\hline
\end{tabular}

\section{DISCUSSION}

The findings of the present investigation revealed that the overall strategy use between the students with more and less exposure to specialized courses had no significant differences. At the category level, the students with less exposure to specialized courses reported significantly more use of reading strategies in the POS category. However, the students with more exposure to specialized courses reported employing the strategies in the sub-category of WHS significantly more frequently. At the individual level, the students with less exposure to specialized courses reported significantly more use of the individual strategies than the students with more exposure to specialized courses.

No previous research has been carried out to investigate the relationships between the Business English majors' levels of exposure to specialized courses and their use of reading strategies. However, two possible factors could be hypothesized to help explain the significant variations in the use of reading strategies between the students with more and less exposure to specialized courses. The two factors are: the difficulty and challenge the students were confronted with in reading and the schemata of the students in business. Regarding the first factor, it could be assumed that the degrees of difficulty and challenge that the students with different levels of exposure to specialized courses were faced with when reading Business English texts were different. As mentioned in Section 2, the students with less exposure to specialized courses were the students in the first and second years. Most of the courses for them were concerning the language skills. The students' focus of study in this phase was on the language knowledge rather than on the business content matter. On the other hand, the courses for the students with more exposure to specialized courses were mainly concerning the business knowledge. The predominant learning task for them was studying the business courses by using English as the medium. Therefore, the students with more exposure to specialized courses would actually involve more English reading relating to business knowledge and they would be more experienced in reading Business English texts than the students with less exposure to specialized courses. Thus, it could be assumed that reading Business English texts would be more difficult and challenging for the students with less exposure to specialized courses than the students with more exposure to specialized courses.

According to Phakiti (2003), learners are likely to be more aware of their performance or behaviors in learning process when they are faced with difficulty. In the present study, it could be inferred that the students with less exposure to specialized courses confronted more difficulties and challenges when reading Business English, and they had to attempt to employ more different strategies to cope with these difficulties and challenges. This could be evidenced by their significantly greater use of the post-reading strategies (POS) than the students with more exposure to specialized courses, which implies that the students with less exposure to specialized courses confronted more difficulties in the 
while-reading stage that they needed to do more compensating activities to enhance their comprehension or solve their difficulties after they finished the actual reading. That the students with more exposure to specialized courses employed significantly more strategies in the SCT sub-category of the WHS category indicates that they were more active in reading strategy use in the while-reading stage. This also supports the point mentioned above. Viewing the individual strategy use, although the students with less exposure to specialized courses seemed to employ more strategies, the students with more exposure to specialized courses were more purposive and had higher metacognitive awareness in strategy use as they employed many effective strategies significantly more frequently than the students with less exposure to specialized courses, such as setting goals or purposes of reading (PRS3), doing fast reading first and peruse later, and adjusting the reading rate accordingly (WHS17), etc.

The second factor that may affect the students' use of reading strategies could be the students' schemata in business. As stated earlier in the introduction part, schema theory emphasizes the importance of the readers' background knowledge. When reading, the readers make use of their schemata to interpret the information in the reading texts. A Schema serves as a bridge to connect the new information with the old information (Perkins and Salomon, 1989). The studies (Carrell, 1983; Barnett, 1989; Bruning, 1995; Brantmeier, 2004) revealed that what students already know (their background knowledge) significantly influences their understanding of L2 reading materials. While reading, the readers' schemata on the topic of the reading text will affect their reading process and will actually influence their use of reading strategies. The readers' schemata for the topic help them to anticipate, to infer, to decide what is or is not important, to build relationships between ideas, or to decide what information merits close attention. After reading, they use their schemata to help them recall what they have read and put it into their own words in order to make them understand what they have read better (Alvermann and Pheps, 2002). In the present study, the students with more exposure to specialized courses used significantly more strategies relating to their content schema, such as using specialized terms as clues or indications (WHS2) and make critical comments and evaluation on the content of the text (POS1), as they have more background knowledge about business that enable them to do so. On the other hand, the students of less exposure to specialized courses seemed to put more effort into decoding the meanings of the words and sentences. They tended to use more strategies in relation to the formal or linguistic schemata, such as reading or check the new word list (PRS4), making use of features of the text (WHS7) and reading every word and sentence slowly and carefully (WHS4), as they did not have that much business background knowledge as the students with more exposure to specialized courses had.

\section{CONCLUSION}

The present study investigated the use of reading strategies by the university Business English majors in Southwest China in terms of their levels of exposure to specialized courses. The results revealed that no significant variations existed in the students' use of reading strategies at the overall level. At the category level, variations were found in the use of reading strategies in the POS category and the SCT sub-category of the WHS category. The students with less exposure to specialized courses reported employing the strategies in the POS category significantly more frequently than the students with more exposure to specialized courses, while the students with more exposure to specialized courses reported significantly greater use of the strategies in the SCT sub-category of the WHS category. At the individual strategy level, the students with less exposure to specialized courses reported employing 12 strategies significantly more frequently than the students with more exposure to specialized courses, whereas the students with more exposure to specialized courses reported employing 6 strategies significantly more frequently than the students with less exposure to specialized courses.

It seems that the students with less exposure to specialized courses employed more strategies than the students with more exposure to specialized courses. However, we found that they actually reported significantly more use of the strategies in the POS category and the strategies involving simple cognition. Whereas, the students with more exposure to specialized courses used the strategies in the SCT sub-category significantly more frequently. They also reported significantly greater use of the strategies relating to metacognition. The findings of the present study indicate that students with less exposure to specialized courses have more difficulties in reading Business English and they are not good at employing more effective and sophiscated strategies to enhance their comprehension when reading Business English texts, especially in the while-reading stage. This means that students of less exposure to specialized courses need more help in Business English reading. Teachers of Business English reading should put more effort to cultivate their strategic awareness, especially the metacognitive awareness, and train them to know how, when, where to use reading strategies to comprehend the Business English texts better.

\section{APPEndiX. STRATEgy QuestionNAIRE FOR Business ENGLISH READING (SQBER)}

This questionnaire is designed to collect the information about the university Business English majors' reading strategy employment when they read their specialized texts. I would like to ask you to do me a favor by answering the following questions concerning how you read business English texts. This is not a test, so there are no 'right' or 'wrong' answers. The aim of the questionnaire is to collect the personal opinions. I do hope to get your sincere answers. 
Your answers to the questionnaire will be used for academic research only and will be treated with the utmost confidentiality. Your cooperation and contribution will be very much appreciated.

Instructions: This questionnaire consists two parts:

Part 1. Personal information

Part 2. Reading strategy items

Part 1. Personal information

Please provide your personal information by putting a tick $(\checkmark)$ in the box of the choices given or write the response where necessary.

Your gender: $\quad \square$ Male

The name of your university:

Academic year of study: $\square$ 1st year $\quad \square$ 2nd year $\quad \square \quad$ 3rd year $\square$ 4th year

You regard your English reading proficiency as:

$\square$ Very good $\quad \square$ Good $\quad \square$ Fair $\quad \square$ Poor $\quad \square$ Very poor

Do you like Business English?

$\square$ Yes $\quad \square$ No

The frequency of reading Business English out of classroom:
$\square$ Never
/Seldom
$\square$ Sometimes
$\square$ Often
$\square$ Every day/almost every day

Part 2

Reading Strategy Questionnaire

Instructions: The following statements are the descriptions about Business English reading strategies. Please read each statement carefully and consider how frequently you employ the given strategies while reading Business English. Please mark your response with a ' $\checkmark$ ' in the corresponding space provided. The answers are just your own opinions and there are no 'right' or 'wrong'. Please give your answers sincerely.

\begin{tabular}{|l|l|}
\hline "Never" & means that you never use the strategy when reading \\
\hline "Sometimes" & means that you occasionally use the strategy when reading \\
\hline "Often" & means that you use the strategy frequently when reading \\
\hline "Always/Almost always & means that you use the strategy most of the time when reading \\
\hline
\end{tabular}

1. Pre-reading Strategies: Before reading Business English texts, do you employ any strategies to help you understand the materials you are going to read? If yes, please specify the frequency.

\begin{tabular}{|l|l|l|l|}
\hline \multirow{2}{*}{ Statements of the strategies } & Frequency of your own reading strategies use \\
\cline { 3 - 4 } & Never & Sometimes & Often \\
\hline 1. Read the title of the text carfully. & & & \\
\hline 2. Construct my related knowledge about the topic. & & & \\
\hline 3. Set goals or purposes of reading. & & & \\
\hline 4. Read or check the new word list. & & & \\
\hline 5. Glance over the foot notes, tables and graphics, etc. (if any) & & & \\
\hline 6. Read the questions about the text. (if any) & & & \\
\hline 7. Read the first and the last paragraphs. & & & \\
\hline 8. Skim the text. & & & \\
\hline 9. Read the first or the last sentence of each paragraph. & & & \\
\hline 10. Make predictions or inference about the content of the text. & & & \\
\hline 11. Search for some related information about the topic. & & & \\
\hline
\end{tabular}

2. While-reading Strategies: While reading Business English texts, do you employ any strategies to enhance your comprehension or solve your reading problems and difficulties? If yes, please specify the frequency. 


\begin{tabular}{|c|c|c|c|c|}
\hline \multirow{2}{*}{$\begin{array}{l}\text { Statements of the reading strategies } \\
\text { (Strategies for comprehending the text) }\end{array}$} & \multicolumn{4}{|c|}{ Frequency of your own reading strategies use } \\
\hline & Never & Sometimes & Often & $\begin{array}{l}\text { Always/Almost } \\
\text { always }\end{array}$ \\
\hline \multicolumn{5}{|l|}{ 12. Pay attention to the key words in the text. } \\
\hline \multicolumn{5}{|l|}{ 13. Use specialized terms as clues or indications. } \\
\hline \multicolumn{5}{|l|}{ 14. Search for the topic sentence of each paragraph. } \\
\hline \multicolumn{5}{|l|}{ 15. Read every word and sentence slowly and carefully. } \\
\hline \multicolumn{5}{|l|}{ 16. Confirm my predictions or inference. } \\
\hline \multicolumn{5}{|l|}{ 17. Raise questions about some information in the text.. } \\
\hline \multicolumn{5}{|l|}{$\begin{array}{l}\text { 18. Make use of the features of the text (e.g. notes, tables } \\
\text { and italics). }\end{array}$} \\
\hline \multicolumn{5}{|l|}{$\begin{array}{l}\text { 19. Consider the logic, coherence and consistency of the } \\
\text { textual information. }\end{array}$} \\
\hline \multicolumn{5}{|l|}{ 20. Draw on my prior knowledge of the topic. } \\
\hline \multicolumn{5}{|l|}{$\begin{array}{l}\text { 21. Take notes or mark the important information in the } \\
\text { text. }\end{array}$} \\
\hline \multicolumn{5}{|l|}{$\begin{array}{l}\text { 22. Pause and think about what I am reading from time to } \\
\text { time. }\end{array}$} \\
\hline \multicolumn{5}{|l|}{ 23. Skip or neglect the unneeded or unimportant content. } \\
\hline \multicolumn{5}{|l|}{ 24. Do fast reading first and peruse later. } \\
\hline \multirow{2}{*}{$\begin{array}{l}\text { Statements of the reading strategies } \\
\text { (Strategies for coping with difficulties) }\end{array}$} & \multicolumn{4}{|c|}{ Frequency of your own reading strategies use } \\
\hline & Never & Sometimes & Often & $\begin{array}{l}\text { Always/Almost } \\
\text { always }\end{array}$ \\
\hline \multicolumn{5}{|l|}{ 25. Analyze the formation of the unknown words. } \\
\hline \multicolumn{5}{|l|}{$\begin{array}{l}\text { 26. Guess the meanings of the words or the sentences from } \\
\text { the context. }\end{array}$} \\
\hline \multicolumn{5}{|l|}{ 27. Analyze the structures of difficult sentences. } \\
\hline \multicolumn{5}{|l|}{ 28. Adjust reading rate accordingly } \\
\hline \multicolumn{5}{|l|}{ 29. Ask the teachers, classmate or friends for help. } \\
\hline \multicolumn{5}{|l|}{ 30. Translate the text into Chinese. } \\
\hline \multicolumn{5}{|l|}{ 31. Make use of word collocations. } \\
\hline \multicolumn{5}{|l|}{ 32. Consult the dictionary for the new words. } \\
\hline \multicolumn{5}{|l|}{ 33. Reread the difficult parts. } \\
\hline \multicolumn{5}{|l|}{ 34. Skip the new words or difficult sentences. } \\
\hline $\begin{array}{l}\text { 35. Consult references to solve my reading problems or } \\
\text { difficulties. }\end{array}$ & & & & \\
\hline
\end{tabular}

3. Post-reading Strategies: After reading Business English texts, do you employ any strategies to help you understand the texts better? If yes, please specify the frequency.

\begin{tabular}{|l|l|l|l|}
\hline \multirow{2}{*}{ Statements of the strategies } & Frequency of your own reading strategies use & $\begin{array}{l}\text { Always/Almost } \\
\text { always }\end{array}$ \\
\cline { 3 - 4 } & Never & Sometimes & Often \\
\hline $\begin{array}{l}\text { 36. Make critical comments and evaluations on the } \\
\text { content of the text. }\end{array}$ & & & \\
\hline 37. Look up the new words in the dictionary & & & \\
\hline $\begin{array}{l}\text { 38. Reflect or evaluate my reading performance and } \\
\text { results. }\end{array}$ & & & \\
\hline 39. Summarize what I read. & & & \\
\hline 40. Review the content of the text. & & & \\
\hline 41. Read other resources about the same topic. & & & \\
\hline 42. Review the notes and marks I made. & & & \\
\hline 43. Conclude my reading problems/difficulties. & & & \\
\hline 44. Summarize the mistakes I made. & & & \\
\hline $\begin{array}{l}\text { 45. Discuss the problems and difficulties with teachers } \\
\text { or friends. }\end{array}$ & & & \\
\hline
\end{tabular}

46. Apart from the strategies mentioned above, are there any strategies that you employ when you read Business English? Please identify:

\section{Thank you very much for your corporation!}

\section{REFERENCES}

[1] Alvermann, D. E. \& Pheps, S. F. (2002). Content reading and literacy ( $3^{\text {rd }}$ ed.). United States of America: A Pearson Education Company.

[2] Anastasiou, D. \& Griva, E. (2009). Awareness of reading strategy use and reading comprehension among poor and good readers. Elementary Education Online, 8 (2), 283-297. 
[3] Anderman, E.M. (1992). Motivation and Cognitive Strategy Use in Reading and writing. Paper presented at the annual meeting of the National Reading Conference, San Antonio, Texas. Available: http://eric.ed.Gov/ ERICWebPortal/search/detailmini. jsp?. (accessed 19/2/2013).

[4] Anderson, J. R. (2000). Learning and memory: An integrated approach ( $2^{\text {nd }}$ ed.). New York: John Whiley.

[5] Anderson, N. J. (1991). Individual differences in strategy use in second language reading and testing. Modern Language Journal, 75, 460-472.

[6] Anderson, N. J. (1999). Exploring second language reading. Beijing: Foreign Language Teaching and Research Press.

[7] Anderson, N. J. (1991). Individual differences in strategy use in second language reading and testing. Modern Language Journal, 75, 460-472.

[8] Anderson, N. J. (2004). Role of the Reader's Schema in Comprehension, Learning, and Memory. In R. B. Ruddell \& N. J. Unrau, (eds.), Theoretical Methods and Processes of Reading ( $5^{\text {th }}$ ed. pp. 594-606). Newark, DE: International Reading Association.

[9] Barnett. M. A. (1988). Reading through Context: How Real and Perceived Strategy Use Affects L2 Comprehension. Modern Language Journal, 72, 150-162.

[10] Barnett, M.A. (1989). More than meets the eye. Foreign language reading: Theory and practice. Englewoods Clifts, N. Jersey: Prentice-Hall.

[11] Block, E. (1986). The comprehension strategies of second language readers. TESOL Quarterly, 20, 463-494.

[12] Brantmeier, C. (2004). Gender, violence-oriented passage content and second language reading comprehension. The Reading Marix, 4 (2), 1-19.

[13] Brown, A. L. (1989). A Practical Guide to Language Learning. New York: Mc Graw-Hill.

[14] Brown, H. (2001). Teaching by principles: An interactive approach to language pedagogy, (2 ${ }^{\text {nd }}$, ed.). White Plains, NY: Pearson Education.

[15] Bruning, R. H. (1995). The college classroom from the perspective of cognitive psychology. In K. Prichard, R. M. Sawyer \& K. Hosteler (eds.), Handbook of College Teaching: Theory and Applications. Westport, CT: Greenwood.

[16] Carrell, P. L. (1983). Some issues in studying the role of schemata, or background knowledge in second language comprehension. Paper presented at the 1983 TESOL convention, Toronto, Ontario, Canada, March 1983.

[17] Chen, J. and Intaraprasert, C. (2014). Reading Strategies Employed by University Business English Majors with Different Levels of Reading Proficiency. English Language Teaching, 7 (4), 25-37.

[18] Davies, F. (1995). Introducing Reading. London: Penguin English.

[19] Goodman, K. (1995). The reading processes. In Carrell, Patricia L., Devine, J. and Eskey, David E. (eds). Interactive approaches to second language reading $\left(6^{\text {th }}\right.$ ed., 11-12). Cambridge: Cambridge University Press.

[20] Graves, M. \& Cooke, C. L. (1980). Effects of previewing difficult short stories for high school students. Research on Reading in Secondary Schools, 6, 38-54.

[21] Hayes, D. A. \& Tierney, R. J. (1982). Developing readers' knowledge through analogy. Reading Research Quarterly, 27, 256-280.

[22] Hosenfeld, C. (1977). A preliminary investigation of the reading strategies of successful and nonsuccessful second language learners. System, 5, 110-123.

[23] Irwin, J.W. (1986). Teaching reading comprehension processes. New Jersey: Prentice-Hall, Inc.

[24] Liu, H. J. (2004). The Relationship between the Metacognitive Strategies and Reading Proficiency. Foreign Languages and Their Teaching, 12, 24-26.

[25] Liu, Y. C. (2002). Differences of Reading Strategies Used by the Successful and Unsuccessful Readers. Foreign Language Teaching Abroad, 3, 24-29.

[26] Liu, Y. L. \& Zhang, J. (2008). An Empirical Study of Reading Strategies Employed by Non-English Majors. Taking Students of Certain College of Guangdong University of Technology as Samples. Joural of Southwest Jiaotong University (Social Sciences). Vol. 9, No. 6, 65-70.

[27] Luo, H. F. (2010). English Reading Text Comprehension Strategies by EFL University Students. Unpublished Doctoral Dissertation, School of Foreign Languages, Suranaree University of Technology, Thailand.

[28] Maarof, N. and Yaacob, R. (2011). Meaning-making in the first and second language: reading strategies of Malaysian students. Procedia Social and Behavioral Sciences, 12, 211-223.

[29] Oxford. R. (1990). Language Learning Strategies: What Every Teacher Should Know. Boston: Heinle \& Heinle Publishers.

[30] Oxford, R. and Nyikos, M. (1989). Variables affecting choice of language learning strategies by university students. The Modern Language journal, 73, 291-300.

[31] Perkins, D. N. and Salomon, G. (1989). Are cognitive skills context-bound? Educational Researcher, 18 (1), 16-25.

[32] Phakiti, A. (2003). A Closer Look at Gender and Strategy Use in L2 Reading. Language Learning, 53 (4), 649-702.

[33] Sheorey, R. and Mokhtari, K. (2001). Differences in the metacognitive awareness of reading strategies among native and non-native readers. System, 29: 431-449.

[34] Song, M. J. (1998). Teaching reading strategies in an ongoing EFL university reading classroom. Asian Journal of English Language Teaching, 8, 41-54.

[35] Zhang, L. J. and Wu A. (2009). Chinese senior high school EFL students' metacognitive awareness and reading-strategy use. Reading in a Foreign Language, 21(1), 37-59. 


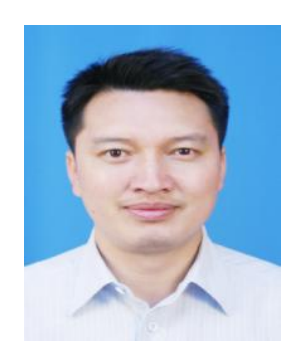

Jun Chen was born in Guizhou Province, China in November 1968. He is currently a Ph.D. candidate in School of Foreign Languages, Institute of Social Technology, Suranaree University of Technology, Thailand. He is currently a teacher of English in the Department of Foreign Languages, Qiannan Normal College for Nationalities, China. He received his master degree in Business English at Dongbei University of Finance and Economics in 2009. His research interests involve second language acquisition and pragmatics.

Channarong Intaraprasert, started teaching English to Thai students in 1984. He is currently working at the School of Foreign Languages, Suranaree University of Technology (SUT), Thailand where he started in 1996 before going to the University of Leeds for his doctoral degree. He is interested in learner beliefs about language learning and how students go about learning a foreign language especially English as a foreign language. Besides, he has been invited to give talk on research in ELT as well as classroom research at different universities in China and Vietnam. He has been teaching research methodology in English Language Studies to both MA and PhD students at his respective University. 